\title{
Bomb blast maculopathy
}

\author{
Thomas Gordon Campbell, ${ }^{1,2}$ Hessom Razavi, ${ }^{3}$ Angus W Turner ${ }^{3}$
}

${ }^{1}$ School of Medicine, University of Queensland, Brisbane, Queensland, Australia 2Princess Alexandra Hospital Brisbane, Queensland, Australia

${ }^{3}$ Lions Outback Vision, Lions Eye Institute, Perth, Western Australia, Australia

\section{Correspondence to}

Dr Thomas Gordon Campbell, thomasgordoncampbell@gmail. com

Accepted 4 November 2014

\section{DESCRIPTION}

A young Afghani man detained in an immigration centre 1500 miles from tertiary eye care presented to an outreach ophthalmology clinic in a remote part of Australia with a history of long-standing visual loss. He reported being blinded in a suicide bomb attack. The patient was 30 feet from the blast and lost consciousness but reported no hearing loss or other injuries. Prior to this incident, the patient reported that he had 'normal vision'.

On examination, the patient had dense bilateral central scotomas. Undilated intraocular pressures were 28 OD and 24 OS (Goldmann tonometry). The patient had no lens or corneal pathology, but dilated funduscopy revealed large, confluent, chorioretinal scars encompassing the macula
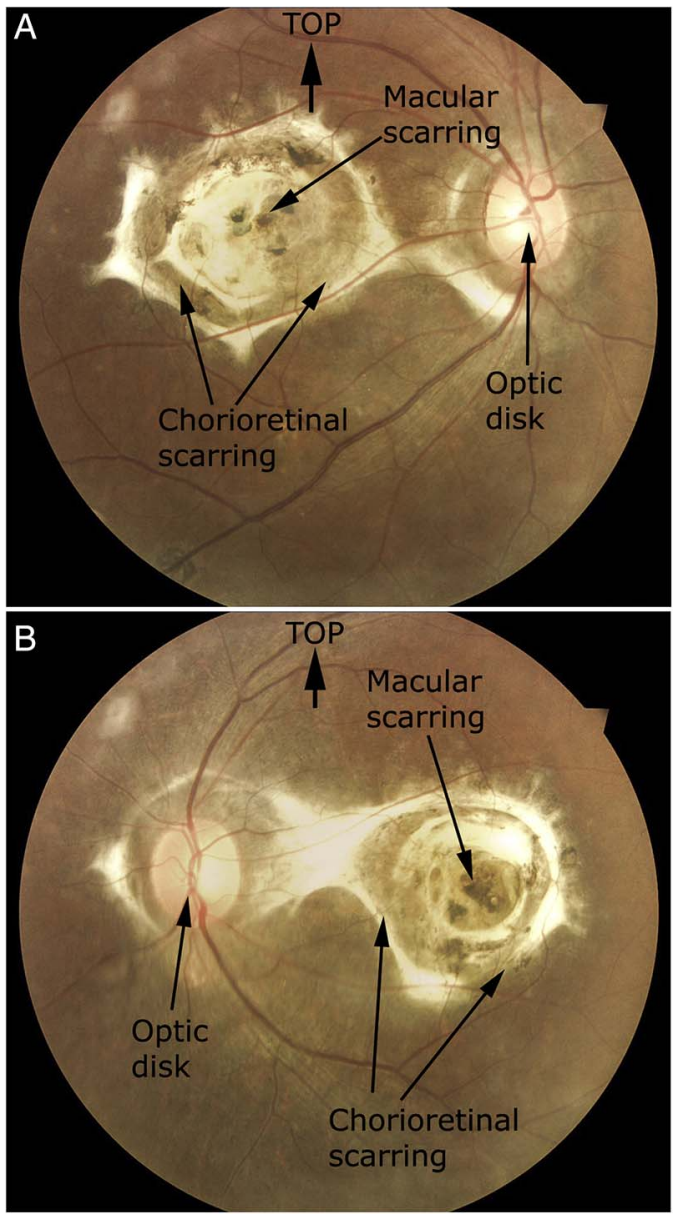

Figure 1 (A and B) Dilated funduscopy revealed large, confluent, chorioretinal scars encompassing the macula bilaterally and extending to the optic nerve head, thought to be due to globe deformation secondary to blast overpressure and subsequent retinal and choroidal injury with likely massive subretinal haemorrhage and retinal pigment epithelium injury. bilaterally and extending to the optic nerve head (see figure 1A, B). The optic nerves appeared to have healthy neural rims.

Ocular injuries are an important cause of morbidity following blast injuries and they affect around $28 \%$ of victims. ${ }^{1}$ Given the recent conflict in Iraq and Afghanistan, ophthalmologists need to be particularly aware of the ocular sequelae of blast-related injuries, the most common of which are corneal abrasions, lacerations and penetrating eye injuries from flying debris and shrapnel. In addition, however, clinicians must be aware that closed-globe retinal and choroidal injuries are also important causes of vision loss. ${ }^{2}$ Between 2000 and late 2010, for example, the American military alone suffered 186555 eye injuries. ${ }^{3}$

Blast-related injuries-such as those inflicted on the Afghani patient-require expert ophthalmic attention, but this is typically unavailable at the remote and/or offshore detention centres where (in accordance with Australian law) asylum seekers are held. The relative absence of tertiary expertise in these centres raises concerns about Australia's capacity to identify and appropriately care for asylum seekers with these injuries, as well as the complex issues arising from them.

\section{Learning points}

- Blast injuries often involve the eyes, and are an important cause of morbidity and disability in people exposed to war and conflicts.

- Closed-globe retinal and choroidal injuries are recognised sequelae of blast exposure and are believed to result from globe deformation from the blast overpressure.

- Remote detention centres may not have the capacity to deal with the complex bio-psychosocial issues arising from cases such as this.

Acknowledgements The authors would like to thank Dr Bruce Campbell for his assistance with the figures in this paper.

\section{Competing interests None.}

Patient consent Obtained.

Provenance and peer review Not commissioned; externally peer reviewed.

\section{REFERENCES}

1 Morley MG, Nguyen JK, Heier JS, et al. Blast eye injuries: a review for first responders. Disaster Med Public Health Prep 2010:4:154-60.

2 Weichel ED, Colyer MH. Combat ocular trauma and systemic injury. Curr Opin Ophthalmol 2008:19:519-25.

3 Hilber DJ. Eye injuries, active component, U.S. Armed Forces, 2000-2010. MSMR 2011:18:2-7. 
Copyright 2014 BMJ Publishing Group. All rights reserved. For permission to reuse any of this content visit http://group.bmj.com/group/rights-licensing/permissions.

BMJ Case Report Fellows may re-use this article for personal use and teaching without any further permission.

Become a Fellow of BMJ Case Reports today and you can:

- Submit as many cases as you like

- Enjoy fast sympathetic peer review and rapid publication of accepted articles

- Access all the published articles

- Re-use any of the published material for personal use and teaching without further permission

For information on Institutional Fellowships contact consortiasales@bmjgroup.com

Visit casereports.bmj.com for more articles like this and to become a Fellow 